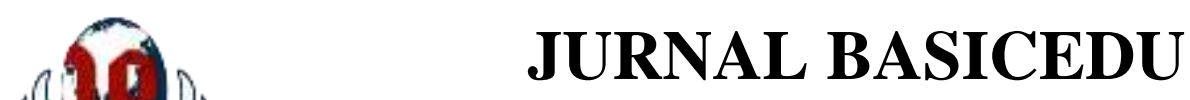

Volume 5 Nomor 5 Tahun 2021 Halaman 3668 - 3676

Research \& Learning in Elementary Education

https://jbasic.org/index.php/basicedu

PAHLATAN

\title{
Pengaruh Model Kooperatif Tipe Think Pair Share terhadap Motivasi dan Kemampuan Komunikasi Matematis Siswa Sekolah Dasar
}

\author{
Bella Putri Zain ${ }^{1 凶}$, Riska Ahmad ${ }^{2}$ \\ Pendidikan Dasar, Universitas Negeri Padang, Indonesia ${ }^{1,2}$ \\ E-mail: bellaputri_zain@yahoo.co.id ${ }^{1}, \underline{\text { ra5402945@gmail.com }}^{2}$
}

\begin{abstract}
Abstrak
Kemampuan komunikasi matematis siswa SDN Gugus III Kecamatan Guguak masih rendah sehingga ini menjadi alasan untuk melakukan penelitian ini. Siswa cendrung pasif dan tidak memahami soal terlebih dahulu serta tidak membuat perencanaan dalam menyelesaikan soal dengan langsung menulis jawaban. Salah satu upaya yang dapat dilakukan adalah dengan menerapkan Model Pembelajaran Kooperatif tipe Think Pair Share (TPS). Jenis penelitian ini adalah quasi eksperimen. Populasi pada penelitian ini adalah siswa kelas V SDN Gugus III Kecamatan Guguak. Sampel penelitian ini adalah siswa kelas V SDN 07 Guguak VIII Koto dan siswa kelas V SDN 11 Guguak VIII Koto Kecamatan Guguak. Data penelitian diperoleh dari hasil tes dan angket. Analisis data menggunakan uji T dan anova dua arah.Hasil penelitian menunjukkan: 1) Kemampuan komunikasi matematis siswa yang belajar dengan model TPS lebih baik dari yang menggunakan pendekatan konvensional. 2) Kemampuan komunikasi matematis siswa dengan motivasi belajar tinggi dan rendah yang mengikuti pembelajaran dengan model TPS lebih baik dari yang menggunakan pendekatan konvensional. 3) Tidak terdapat interaksi antara model pembelajaran dengan motivasi belajar dalam mempengaruhi kemampuan komunikasi matematis.
\end{abstract}

Kata Kunci: kemampuan komunikasi, motivasi belajar, think pair share.

\begin{abstract}
The mathematical communication ability of the students of SDN Cluster III Guguak District is still low. So that is the reason for conducting this research. Students tend to be passive and do not understand about it beforehand and do not make plans in completing it first by directly writing answers. One of the efforts that can be done is to apply the Think Pair Share (TPS) Cooperative Learning Model. This type of research is quasy experiment. The populations in this research were fifth grade students of Gugus III Elementary School Kecamatan Guguak. The sample of this research wasthe fifth grade students of SDN 07 Guguak VII Koto ,the fifth grade students of SDN 11 Guguak VIII Koto Kecamatan Guguak. The research data was obtained from the results of tests and questionnaires. Data analysis used T-test and two-way Anova. The results of theresearch show: 1) The mathematical communication ability of students learning with TPS model is better than using conventional approach. 2) Mathematical communication skills of students with high and low learning motivation who follow learning with the TPS model are better than those using conventional approaches. 3) There is no interaction between learning models and learning motivation in influencing mathematical communication skills.
\end{abstract}

Keywords: The mathematical communication ability, learning motivation, Think Pair Share.

Copyright (c) 2021 Bella Putri Zain, Riska Ahmad

Corresponding author :

Email : bellaputri_zain@yahoo.co.id

DOI : https://doi.org/10.31004/basicedu.v5i5.1408

ISSN 2580-3735 (Media Cetak)

ISSN 2580-1147 (Media Online)

Jurnal Basicedu Vol 5 No 5 Tahun 2021

p-ISSN 2580-3735 e-ISSN 2580-1147 


\section{PENDAHULUAN}

Matematika merupakan bidang studi yang dipelajari oleh semua siswa dari SD hingga SLTA dan bahkan juga di perguruan tinggi. Matematika juga sebagai ilmu yang berpengaruh dalam perkembangan ilmu dan teknologi, sehingga perlu diajarkan melalui proses pembelajaran yang bermakna bagi siswa(Vivi, Fitria, Miaz, \& Ahmad, 2020). Oleh karena itu penting untuk mewujudkan tujuan utama pembelajaran matematika di sekolah agar siswa memiliki kemampuan matematis yang memadai untuk melanjutkan pendidikan ke jenjang yang lebih tinggi dan untuk menyelesaikan masalah dalam kehidupan sehari-hari. Tujuan yang sudah dibuat dengan sangat baik tersebut belum sepenuhnya terwujud dalam pembelajaran matematika (Ediyanto, Gistituati, Fitria, \& Zikri, 2020). Pembelajaran matematika seharusnya dapat mengembangkan kemampuan siswa untuk memahami ide yang terdapat pada simbol, diagram dan media lainnya serta mengunakannya untuk menuangkan ide, memodelkan permasalahan dan menyelesaikannya(Taufina, Chandra, Fauzan, \& Ilham Syarif, 2019).

Kenyataannya, kemampuan siswa dalam memahami simbol dan menggunakannya dalam pemecahan masalah belum begitu memuaskan. Analisis terhadap hasil kerja siswa menunjukkan rendahnya kemampuan komunikasi matematisnya (Zaroha, 2019). Respon siswa terhadap pembelajaran juga menjadi sesuatu yang sangat penting untuk diperhatikan. Hal ini disebabkan karena pembelajaran adalah proses interaksi yang dilakukan oleh guru dan siswa di dalam maupun di luar kelas dengan menggunakan berbagai sumber belajar sebagai bahan kajian. Interaksi antara guru dan siswa akan efektif jika berlangsung dua arah. Guru diharapkan menciptakan proses pembelajaran yang dapat memunculkan respons siswa. Respons siswa dapat dilihat dari partisipasi siswa selama proses pembelajaran(Abduljabar, 2014).

Berdasarkan observasi yang dilakukan penulis di SDN 07 Guguak VIII Koto Kecamatan Guguak pada semester 1 Tahun Pelajaran 2020/2021 di kelas V, proses pembelajaran matematika belum sepenuhnya melibatkan seluruh siswa untuk ikut dalam mengkomunikasikan materi matematika yang dipelajari. Penyampaian materi masih bersifat informatif, artinya guru lebih dominan dalam memberi tahu siswa tentang materi pelajaran. Guru belum menciptakan komunitas matematika dalam kelas. Kurangnya interaksi siswa dengan siswa dalam proses pembelajaran. Selanjutnya guru merupakan bagian penting yang turut andil dalam menciptakan komunitas matematika di kelas. Selain itu kenyataan di lapangan menunjukkan bahwa hasil pembelajaran matematika dari aspek kemampuan komunikasi serta memecahkan masalah matematika masih rendah, hal ini juga ditemukan oleh (Roqib, 2013)yang menemukan bahwa kemampuan pemecahan masalah siswa dalam pembelajaran matematika rendah dan perlu ditingkatkan, selain itu komunikasi matematis siswa masih rendah dikarenakan kurangnya motivasi dari siswa dimana ciri-ciri siswa yang kurang termotivasi dapat terlihat dari siswa yang cepat bosan dalam belajar, melamun, malas menyelesaikan tugas dan enggan memperhatikan guru.

Karena jika tidak ada motivasi dari siswa untuk belajar, maka selamanya siswa tidak akan tertarik dengan pelajaran matematika dan tidak memperoleh kepuasan dari belajar matematika dan belajar menjadi tidak bermakna.Hal tersebut sejalan dengan penelitian yang dilakukan oleh (Vivi et al., 2020) untuk belajar sangat diperlukan adanya motivasi, adanya motivasi yang tinggi dalam belajar akan manunjukkan hasil yang baik. Motivasi berpengaruh dalam meningkatkan hasil belajar siswa. Hal tersebut juga sesuai dengan hasil observasi dan tanya jawab yang dilakukan di SD Gugus III Kecamatan Guguak pada tanggal 06 dan 07 Januari 2020 bahwa kemampuan matematis serta motivasi belajar siswa pada pelajaran matematika masih sangat rendah.

Berdasarkan hasil wawancara dengan enam orang guru SD Gugus III Kecamatan Guguak pada saat kegiatan KKG kelas tinggi di SD 03 Guguak VIII Koto Kecamatan Guguak bahwa kurangnya partisipasi siswa secara aktif dalam proses pembelajaran, siswa cepat melupakan materi pelajaran meskipun materi tersebut baru saja disampaikan yang mengakibatkan sulitnya memahami materi selanjutnya, siswa kesulitan 
dalam mengerjakan soal cerita, jika diberikan soal yang berbeda dari yang diajarkan guru maka siswa akan sulit menyelesaikannya.

Adapun faktor yang dapat mempengaruhi kemampuan matematis dan motivasi belajar siswa adalah perlunya inovasi pembelajaran. Inovasi tersebut bisa berupa penerapan model pembelajaran yang mampu memberi kesempatan kepada siswa untuk dapat mengemukakan ide-ide dan gagasannya. Motivasi sangat penting untuk membangkitkan minat siswa terhadap proses pembelajaran disetiapsituasi belajar mengajar (Miaz, 2012). Pada motivasi tingkat dasar sangat berperan penting dibandingkan dengan tingkat pembelajaran lainnya karena fakta bahwa pelajar dasar perlu termotivasi untuk belajarsaat mereka mengalami pengetahuan baru. Guru sebagai sumber belajar, penentu metode dan model pembelajaran, dan juga penilai kemajuan belajar siswa untuk menjadikan pembelajaran lebih efektif dan efisien untuk mencapai tujuan pembelajaran itu sendiri (Husada, Taufina, \& Zikri, 2020).

Adanya suatu pembelajaran yang lebih tepat dan menarik perlu dilaksanakan, dimana siswa dapat belajar secara kooperatif, dapat bertanya meskipun tidak pada guru secara langsung, mengemukakan pendapat dan interaksi siswa lebih meningkat (Abdi \& Hasanuddin, 2018). Salah satu tipe belajar yang memenuhi syarat tersebut dan mudah untuk diterapkan adalah model pendekatan struktural dengan tipe think pair share (TPS) yang merupakan salah satu bagian dari pembelajaran kooperatif (cooperative learning). Sejalan dengan pendapat (Irianto, 2016) yang mengemukakan think pair share sebagai salah satu tipe dalam pembelajaran kooperatif, memberi kesempatan pada siswa untuk berpikir, berpasangan atau bekerja dengan partner, berbagi, dan saling membantu satu sama lain, sehingga mampu menambah variasi model pembelajaran yang lebih menarik, menyenangkan, meningkatkan aktivitas, serta kerja sama siswa.

Selain itu dari hasil penelitian yang dilakukan menyebutkan bahwa implementasi metode cooperative learning model think pair share berdampak positif terhadap peningkatan aktivitas belajar siswa, perbaikan suasana pembelajaran, maupun peningkatan hasil belajar para siswa. Sejalan dengan itu (Wyn, Sutrisni, Suadnyana, \& Suardika, n.d.) menyatakan bahwa penerapan model Think Pair Share dapat meningkatkan aktivitas siswa, motivasi siswa, dan hasil belajar siswa.

Dengan demikian tujuan penelitian ini adalah untuk melihat pengaruh model pembelajaran kooperatif tipe think pair share dan motivasi belajar terhadap kemampuan komunikasi matematis siswa sekolah dasar.

\section{METODE PENELITIAN}

Jenis penelitian yang digunakan dalam penelitian ini yaitu eksperimen. Rancangan penelitian yang digunakan adalah Randomized Control Group Only Design (Creswell, 2016), karena penelitian ini ingin mengetahui pengaruh suatu perlakuan terhadap suatu variabel. Pada penelitian ini perlakuan yang diberikan pada kelas eksperimen adalah penerapan Model pembelajaran kooperatif tipe Think Pair Share terhadap motivasi dan kemampuan komunikasi matematis siswa. Sementara pada kelas kontrol menggunakan pembelajaran konvensional. Populasi dalam penelitian ini adalah seluruh siswa kelas V SDN Gugus III Kecamatan Guguak yang terdaftar pada tahun ajaran 2020/2021 yang memiliki kurikulum dan KKM yang sama yaitu kurikulum 2013 dan KKM 75. Pengambilan sampel diambil secara "random sampling". Dalam pelaksanaan penelitian, untuk memperoleh data maka dilakukan langkah-langkah sebagai berikut: memberikan angket motivasi belajar matematika pada kelas kontrol dan kelas eksperimen. Memberikan tes akhir kepada kelas kontrol dan kelas eksperimen setelah diberikan perlakuan. Teknik yang digunakan dalam penganalisisan data penelitian sebagai berikut: analisis butir angket motivasi, analisis data hasil belajar siswa, uji normalitas dan homogenitas(Sugiyono, 2013). 
3671 Pengaruh Model Kooperatif Tipe Think Pair Share terhadap Motivasi dan Kemampuan Komunikasi Matematis Siswa Sekolah Dasar-Bella Putri Zain, Riska Ahmad

DOI: https://doi.org/10.31004/basicedu.v5i5.1408

\section{HASIL DAN PEMBAHASAN}

Data hasil penelitian yang dideskripsikan adalah data tes akhir yaitu kemampuan komunikasi matematis siswa. Setelah dilakukan perhitungan diperoleh hasil tes kemampuan komunikasi siswa kelas eksperimen dan kelas kontrol yang terlihat pada tabel 1 .

Tabel 1 Hasil Tes Kemampuan Komunikasi Matematis

\begin{tabular}{lcccccc}
\hline Kelas & N & $\begin{array}{c}\text { Skor } \\
\text { Maksimum } \\
\text { Ideal }\end{array}$ & $\begin{array}{c}\text { Rata- } \\
\text { rata }\end{array}$ & $\begin{array}{c}\text { Simpangan } \\
\text { Baku }\end{array}$ & $\begin{array}{c}\text { Skor } \\
\text { Maksimum }\end{array}$ & $\begin{array}{c}\text { Skor } \\
\text { Minimu } \\
\text { m }\end{array}$ \\
\hline Eksperimen & 24 & 100 & 78,03 & 11,07 & 100 & 64,28 \\
\hline Kontrol & 24 & 100 & 62,67 & 17,39 & 85,71 & 28,57 \\
\hline
\end{tabular}

Pada tabel 1 terlihat bahwa rata-rata hasil tes kemampuan komunikasi matematis siswa yang diajar dengan menggunakan model TPS lebih tinggi daripada rata-rata hasil tes kemampuan komunikasi matematis siswa yang diajar dengan pendekatan konvensional. Berdasarkan data simpangan baku maka nilai tes kemampuan komunikasi siswa kelas kontrol lebih menyebar dibandingkan nilai tes kemampuan komunikasi siswa kelas eksperimen. Karena simpangan baku kelas eksperimen lebih kecil daripada kelas.

Data hasil tes kemampuan komunikasi siswa dikelompokkan berdasarkan motivasi belajar tinggi dan rendah. Cara menentukan kelompok siswa dengan motivasi tinggi dan rendah adalah dengan menjumlahkan skor motivasi belajar kelas eksperimen dan kelas kontrol. Siswa yang memiliki nilai skor di atas rata-rata dikelompokkan kepada siswa dengan motivasi belajar tinggi. Siswa yang memiliki nilai skor di bawah ratarata dikelompokkan kepada siswa dengan motivasi belajar rendah.

Deskripsi data kemampuan komunikasi siswa yang memiliki motivasi belajar tinggi dan rendah pada kelas eksperimen dan kelas kontrol dapat di lihat pada tabel 2.

Tabel 2 Hasil Tes Kemampuan Komunikasi Matematis Siswa berdasarkan Motivasi Belajar

\begin{tabular}{cclccccc}
\hline No. & Kelas & $\begin{array}{c}\text { Motivasi } \\
\text { Belajar }\end{array}$ & $\mathbf{N}$ & Mean & $\begin{array}{c}\mathbf{X} \\
\text { minimum }\end{array}$ & $\begin{array}{c}\mathbf{X} \\
\text { maksimum }\end{array}$ & s \\
\hline $\mathbf{1}$ & Eksperimen & Tinggi & 13 & 82,74 & 64,3 & 100 & 11,48 \\
\cline { 2 - 8 } & Rendah & 11 & 71 & 64,3 & 78,6 & 5,54 \\
\hline $\mathbf{2}$ & \multirow{2}{*}{ Kontrol } & Tinggi & 9 & 70,63 & 50 & 85,71 & 13,45 \\
\cline { 2 - 8 } & Rendah & 15 & 56,2 & 28,6 & 75 & 18,07 \\
\hline
\end{tabular}

\section{Pengujian Prasyarat Analisis}

Sebelum pengujian hipotesis, terlebih dahulu dilakukan uji persyaratan analisis yaitu data hasil kemampuan pemecahan masalah dan komunikasi matematis yang diajar dengan menggunakan model TPS dan dengan menggunakan pendekatan konvensional. Uji persyaratan analisis yang pertama dilakukan yaitu uji normalitas dengan menggunakan uji Lilliefors dan uji homogenitas variansi menggunakan uji Bartlett.

\section{Uji Normalitas}

Uji normalitas nilai tes kemampuan pemecahan masalah dan komunikasi matematis siswa kelas eksperimen dan kelas kontrol dilakukan dengan menggunakan uji Lilliefors pada taraf signifikan $a=0,05$. Hasilnya dapat dillihat pada tabel 3 .

Tabel 3 Uji Normalitas Tes Kemampuan Komunikasi Matematis

\begin{tabular}{ccccc}
\hline $\begin{array}{c}\text { Motivasi } \\
\text { Belajar }\end{array}$ & Eksperimen & Keterangan & Kontrol & Keterangan \\
\hline Tinggi & 0,200896 & Normal & 0,131212 & Normal \\
\hline
\end{tabular}


3672 Pengaruh Model Kooperatif Tipe Think Pair Share terhadap Motivasi dan Kemampuan Komunikasi Matematis Siswa Sekolah Dasar-Bella Putri Zain, Riska Ahmad

DOI: https://doi.org/10.31004/basicedu.v5i5.1408

\begin{tabular}{ccccc}
\hline Rendah & 0,217917 & Normal & 0,148765 & Normal \\
\hline
\end{tabular}

Pada tabel 3 dapat dilihat bahwa skor kemampuan komunikasi matematis siswa kelas eksperimen dan kelas kontrol berdistribusi normal.

\section{Uji Homogenitas}

Hasil uji homogenitas variansi kemampuan komunikasi matematis siswa pada kelas eksperimen dan kelas kontrol dapat dilihat pada tabel 4 .

Tabel 4 Uji Homogentis Tes Kemampuan Komunikasi Matematis

\begin{tabular}{ccc}
\hline Motivasi Belajar & Signifikan & Keterangan \\
\hline Tinggi & 0,15159 & Homogen \\
\hline Rendah & 0,4270 & Homogen \\
\hline
\end{tabular}

Pada tabel 4 dapat dilihat bahwa skor kemampuan komunikasi matematis siswa kelas eksperimen dan kelas kontrol memiliki variansi homogen.

\section{Pengujian Hipotesis}

Pengujian hipotesis bertujuan untuk melihat signifikansi dari perlakuan yang ditetapkan terhadap sampel penelitian. Penelitian ini memiliki empat hipotesis. Hipotesis 1-3 menggunakan uji t karena data berdistribusi normal dan memiliki variansi homogen sedangkan hipotesis 4 menggunakan uji Anova Dua Arah yang akan diuraikan sebagai berikut.

\section{Hipotesis Pertama}

Hasil perhitungan uji hipotesis pertama dapat dilihat pada Tabel 5.

Tabel 5 Hasil Uji Hipotesis 1

\begin{tabular}{lccccccc}
\hline \multicolumn{1}{c}{ Kelas } & $\mathbf{N}$ & $\mathbf{S}_{\text {gab }}$ & $\mathbf{a}$ & $\mathbf{D k}$ & $\mathbf{t}_{\text {hitung }}$ & $\mathbf{t}_{\text {tabel }}$ & Keterangan \\
\cline { 1 - 3 } Eksperimen & 24 & \multirow{2}{*}{14,58} & 0,05 & 48 & 3,339 & 2,025 & Terima $\mathrm{H}_{1}$ \\
\hline Kontrol & 24 & & & & & & \\
\hline
\end{tabular}

Pada tabel 5 terlihat bahwa hasil kemampuan komunikasi matematis siswa yang diajar dengan menggunakan model TPS lebih tinggi dibandingkan dengan menggunakan pendekatan konvensional . Karena hasil tes kemampuan komunikasi matematis siswa kelas eksperimen dan kelas kontrol mempunyai nilai sign < taraf nyata $\mathrm{a}=0,05$. Artinya, tolak $\mathrm{H}_{0}$ dan terima $\mathrm{H}_{1}$.

\section{Hipotesis Kedua}

Hasil perhitungan uji hipotesis kedua untuk kemampuan komunikasi dengan motivasi belajar tingggi dapat dilihat pada tabel 6.

Tabel 6 Hasil Uji Hipotesis 2

\begin{tabular}{lccccccc}
\hline \multicolumn{1}{c}{ Kelas } & $\mathbf{N}$ & $\mathbf{S}_{\text {gab }}$ & $\mathbf{a}$ & $\mathbf{D k}$ & $\mathbf{t}_{\text {hitung }}$ & $\mathbf{t}_{\text {tabel }}$ & Keterangan \\
\cline { 1 - 2 } Eksperimen & 13 & \multirow{2}{*}{12,35} & 0,05 & 24 & 2,276 & 2,093 & Terima $\mathrm{H}_{1}$ \\
\hline Kontrol & 11 & & & & &
\end{tabular}

Pada tabel terlihat bahwa hasil tes kemampuan komunikasi matematis siswa dengan motivasi belajar tinggi kelas eksperimen dan kelas kontrol mempunyai nilai sign $<$ taraf nyata $a=0,05$. Artinya, tolak $\mathrm{H}_{0}$ dan terima $\mathrm{H}_{1}$, sehingga dapat disimpulkan bahwa hasil kemampuan komunikasi matematis siswa yang memiliki 
3673 Pengaruh Model Kooperatif Tipe Think Pair Share terhadap Motivasi dan Kemampuan Komunikasi Matematis Siswa Sekolah Dasar-Bella Putri Zain, Riska Ahmad

DOI: https://doi.org/10.31004/basicedu.v5i5.1408

motivasi belajar tinggi yang diajar dengan menggunakan model TPS lebih tinggi dibandingkan dengan menggunakan pendekatan konvensional.

\section{Hipotesis Ketiga}

Hasil perhitungan uji hipotesis ketiga pada tes kemampuan komunikasi matematis siswa dengan motivasi belajar rendah kelas eksperimen dan kelas kontrol mempunyai nilai sign $<$ taraf nyata a $=0,05$. Artinya, tolak $\mathrm{H}_{0}$ dan terima $\mathrm{H}_{1}$, sehingga dapat disimpulkan bahwa hasil kemampuan komunikasi matematis siswa yang memiliki motivasi belajar rendah yang diajar dengan menggunakan model TPS lebih tinggi dibandingkan dengan menggunakan pendekatan konvensional. Hasil perhitungan dapat dilihat pada tabel.7.

Tabel 7 Hasil Uji Hipotesis 3

\begin{tabular}{cccccccc}
\hline Kelas & $\mathbf{N}$ & $\mathbf{S}_{\text {gab }}$ & $\mathbf{a}$ & $\mathbf{D k}$ & $\mathbf{t}_{\text {hitung }}$ & $\mathbf{t}_{\text {tabel }}$ & Keterangan \\
\cline { 1 - 3 } Eksperimen & 9 & \multirow{2}{*}{14,314} & 0,05 & 24 & 2,247 & 2,110 & Terima $\mathrm{H}_{1}$ \\
\cline { 1 - 2 } & 15 & & & & & & \\
\hline
\end{tabular}

\section{Hipotesis Keempat}

Hipotesis keempat digunakan untuk mengetahui interaksi antara model TPS dan motivasi belajar dalam mempengaruhi kemampuan komunikasi matematis siswa. Hasil perhitungan dapat dilihat pada Tabel 8.

Tabel 8 Hasil Uji Hipotesis 4

\begin{tabular}{lccccc}
\hline \multicolumn{1}{c}{ Sumber Varians } & JK & Dk & RJK & $\mathbf{F}_{\text {hitung }}$ & $\mathbf{F}_{\text {tabel }}$ \\
\hline Antar A & 3424,457 & 1 & 3424,457 & 8,909 & 4,09 \\
\hline Antar B & 1474,490 & 1 & 1474,490 & 3,836 & 4,09 \\
\hline Interaksi A x B & 508,50754 & 1 & 508,50754 & 1,322 & 4,09 \\
\hline Dalam & 14990,804 & 47 & 384,379 & & \\
\hline Total & 19381,378 & 47 & - & & \\
\hline
\end{tabular}

Berdasarkan hasil perhitungan uji Anova Dua Arah pada tabel diperoleh nilai Sig.4,09. Nilai signifikansi lebih besar dari $\mathrm{a}=0,05$, maka $\mathrm{H}_{0}$ diterima atau tidak terdapat interaksi antara model TPS dan motivasi belajar terhadap kemampuan komunikasi matematis siswa.

Penelitian ini dilakukan selama empat kali pertemuan, dengan materi pengolahan data dan penyajian data. Proses pembelajaran pada kelas eksperimen diberikan perlakuan menggunakan mode TPS, sedangkan kelas kontrol dengan pembelajaran konvensional. Pada akhir pembelajaran kedua kelas diberikan tes akhir yang sama untuk mengetahui kelas mana yang memiliki hasil belajar yang lebih tinggi. Dalam hal ini hasil belajarnya berupa kemampuan komunikasi matematis, serta motivasi belajar siswa.

\section{Pengaruh Model TPS terhadap Kemampuan Komunikasi Matematis Siswa Kelas Eksperimen dan Kelas Kontrol}

Berdasarkan hasil tes akhir siswa dapat dilihat bahwa nilai rata-rata kemampuan komunikasi matematis siswa kelas eksperimen yang belajar menggunakan model TPS lebih tinggi dibandingkan dengan nilai ratarata kelas kontrol yang belajar menggunakan pendekatan konvensional. Hal ini terlihat dari rata-rata skor kemampuan komunikasi matematis siswa kelas eksperimen yaitu 78,03 sedangkan rata-rata skor kemampuan komunikasi matematis kelas kontrol yaitu 62,67. Skor tertinggi kelas eksperimen yaitu 100 dan terendah adalah 64,28. Sedangkan skor tertinggi kelas kontrol adalah 85,71 dan skor terendah adalah 28,57

TPS merupakan suatu model pembelajaran yang disusun untuk memecahkan masalah, model TPS merupakan gabungan strategi individual dan kelompok dengan memberikan permasalahan nyata kepada siswa dan melatih siswa mengkomunikasikan ide matematisnya dengan membuat gambar, simbol dan penjelasan 
3674 Pengaruh Model Kooperatif Tipe Think Pair Share terhadap Motivasi dan Kemampuan Komunikasi Matematis Siswa Sekolah Dasar - Bella Putri Zain, Riska Ahmad

DOI: https://doi.org/10.31004/basicedu.v5i5.1408

dalam bentuk tulisan dengan bahasa sendiri untuk menyelesaikan masalahnya. Siswa memecahkan masalah secara individual kemudian siswa mengkomunikasikannya di dalam kelompok untuk didiskusikan dan saling dibahas, dimana semua anggota kelompok bertanggung jawab atas keseluruhan jawaban sebagai tanggung jawab bersama dan mempersentasikannya di depan kelas. Sehingga siswa dapat terlatih dalam kemampuan komunikasi matematisnya (Fitri, S, \& Zikri, 2019).

Kemampuan komunikasi siswa yang mengikuti pembelajaran dengan model TPS lebih baik karena pada pembelajaran siswa dapat belajar bersama, saling membantu, mengintegrasikan pengetahuan baru dengan pengetahuan yang telah ia miliki, dan menemukan pemahamannya sendiri lewat eksplorasi, diskusi, menjelaskan serta mengkomunikasikan dalam kelompoknya.

Pada pembelajaran konvensional pembelajaran juga diawali dengan masalah, namun pada kegiatan pembelajaran belum mengontruksi pengetahuan siswa untuk memecahkan masalah sendiri serta belum melatih siswa dalam komunikasi matematis. Karena siswa hanya mengetahui apa yang diberikan oleh gurunya dan berpedoman pada apa yang telah dijelaskan guru. (Majid, 2013:194).

Pada penelitian ini soal tes komunikasi terdiri dari enam soal yang disusun berdasarkan indikator komunikasi matematis. Indikator yang digunakan yaitu (1) menyatakan peristiwa sehari-hari dalam bahasa atau simbol matematika (2) menjelaskan ide, situasi, dan relasi matematika secara tulisan dengan grafik dan aljabar (3) kemampuan mengomunikasikan strategi penyelesaian suatu masalah matematis(Yulia, Fauzan, Gistituati, \& Yerizon, 2018).

Pada indikator menjelaskan ide, situasi, dan relasi matematika secara tulisan dengan grafik dan aljabar, siswa kelas eksperimen tepat menggambarkan gambar begitu juga dengan kelas kontrol. Perbedaannya terletak pada pemberian simbol dan keterangan pada gambar.

\section{Interaksi antara Model Pembelajaran dan Motivasi Belajar terhadap Kemampuan Komunikasi Matematis Siswa}

Interaksi merupakan variasi dua variabel bebas atau lebih dalam mempengaruhi satu variabel terikat. Interaksi berarti bahwa pengaruh dari suatu variabel bebasterhadap variabel terikat, bergantung pada taraf atau tingkat variabel lainnya. Hasil pengujian hipotesis yang berkaitan dengan interaksi pada penelitian ini membuktikan bahwa tidak terdapat interaksi antara model pembelajaran dan motivasi terhadap hasil kemampuan pemecahan masalah dan komunikasi matematis siswa. Artinya, model pembelajaran yang digunakan dan motivasi belajar siswa tidak saling ketergantungan dalam mempengaruhi kemampuan pemecahan masalah dan komunikasi matematis siswa.

Tidak terdapatnya interaksi dapat terjadi apabila lebih dari satu variabel membawa pengaruh terpisah yang signifikan atau main effect. Siswa yang memiliki motivasi belajar tinggi ketika diajarkan dengan model TPS memiliki kemampuan komunikasi matematis yang lebih tinggi daripada siswa yang diajarkan dengan model konvensional. Hal tersebut dapat terlihat dari rata-rata skor kemampuan komunikasi kelas eksperimen 82,74 dan rata-rata kelas kontrol 62,67.

Begitu juga, siswa yang memiliki motivasi belajar rendah ketika diajarkan dengan model model TPS memiliki kemampuan komunikasi matematis yang lebih tinggi daripada siswa yang diajarkan dengan model konvensional. Hal ini dapat dilihat dari rata-rata skor kemampuan komunikasi motivasi rendah kelas eksperimen yaitu 71,00 dan kelas kontrol 56,2. Berdasarkan rata-rata skor tersebut, berarti model TPS mampu mempengaruhi kemampuan komunikasi matematis siswa dengan kondisi motivasi belajar apapun yang dimiliki siswa, karena model TPS dan motivasi belajar memiliki pengaruh masing-masing terhadap hasil belajar. Hasil penelitian ini sesuai dengan pendapat (Fatimah, 2015)yang menyatakan bahwa, adanyapengaruh utama yang kuat sehingga melemahkan interaksi yang ada. Interaksi yang tidak signifikan menunjukkan bahwa pengaruh variabel lain (selain tindakan) tidak cukup signifikan untuk mempengaruhi pencapaian belajar siswa (Abdi \& Hasanuddin, 2018). Dalam penelitian ini, model TPS tepat digunakan pada siswa yang 
3675 Pengaruh Model Kooperatif Tipe Think Pair Share terhadap Motivasi dan Kemampuan Komunikasi Matematis Siswa Sekolah Dasar - Bella Putri Zain, Riska Ahmad

DOI: https://doi.org/10.31004/basicedu.v5i5.1408

memiliki motivasi tinggi maupun siswa yang memiliki motivasi rendah dalam meningkatkan kemampuan matematis siswa.

Berdasarkan uraian tersebut, model pembelajaran dan motivasi belajar siswa memiliki pengaruh yang terpisah dalam mempengaruhi kemampuan pemecahan masalah dan komunikasi matematis siswa. Sehingga dapat disimpulkan bahwa tidak terdapat interaksi antara model pembelajaran dan motivasi terhadap kemampuan komunikasi matematis siswa.

\section{SIMPULAN}

Penelitian ini merupakan penelitian yang membandingkan penggunaan model TPS dan pendekatan konvensional. Penelitian ini bertujuan untuk melihat kemampuan matematis, khususnya kemampuan komunikasi matematis serta motivasi belajar matematika siswa. Berdasarkan analisis data yang telah dikemukakan, maka dapat disimpulkan bahwa. 1) Kemampuan komunikasi matematis siswa yang mengikuti pembelajaran dengan menggunakan model TPS lebih tinggi dibandingkan kemampuan komunikasi matematis siswa yang mengikuti pembelajaran dengan pendekatan konvensional. 2) Kemampuan komunikasi matematis siswa yang memiliki motivasi belajar tinggi yang mengikuti pembelajaran dengan menggunakan model TPS lebih tinggi dibandingkan kemampuan komunikasi matematis siswa yang memiliki motivasi belajar tinggi yang mengikuti pembelajaran dengan pendekatan konvensional. 3) Kemampuan komunikasi matematis siswa yang memiliki motivasi belajar rendah yang mengikuti pembelajaran dengan menggunakan model TPS lebih tinggi dibandingkan kemampuan komunikasi matematis siswa yang memiliki motivasi belajar rendah yang mengikuti pembelajaran dengan pendekatan konvensional. 4) Tidak terdapat interaksi antara model TPS dengan motivasi belajar dalam mempengaruhi kemampuan komunikasi matematis siswa.

\section{DAFTAR PUSTAKA}

Abdi, M., \& Hasanuddin, H. (2018). Pengaruh Model Pembelajaran Think Pair Share Dan Motivasi Belajar Terhadap Kemampuan Komunikasi Matematis Siswa Sekolah Menengah Pertama. Juring (Journal For Research In Mathematics Learning), 1(2), 99. Https://Doi.Org/10.24014/Juring.V1i2.4778

Abduljabar, B. (2014). Memperkokoh Pendidikan Karakter Melalui Mediasi Aktivitas Jasmani Berbasis Nilai. Jurnal Pendidikan Karakter, 4(1), 97-107.

Ananda, R. (2017). Peningkatan Hasil Belajar Siswa Pada Materi Operasi Pengurangan Bilangan Cacah Dengan Menggunakan Blok Dienes Siswa Kelas I Sdn 016 Bangkinang Kota. Jurnal Cendekia: Jurnal Pendidikan Matematika, l(1), 11.

Ananda, R. (2018). Penerapan Pendekatan Realistics Mathematics Education (Rme) Untuk Meningkatkan Hasil Belajar Matematika Siswa Sekolah Dasar. Jurnal Cendekia: Jurnal Pendidikan Matematika, 2(1), $125-133$.

Ananda, R., Fadhilaturrahmi, F., \& Hanafi, I. (2021). Dampak Pandemi Covid-19 Terhadap Pembelajaran Tematik Di Sekolah Dasar. Jurnal Basicedu, 5(3), 1689-1694.

Creswell, J. W. (2016). Research Design: Pendekatan Metode Kualitatif, Kuantitatif, Dan Campuran. In Sage Publication.

Ediyanto, E., Gistituati, N., Fitria, Y., \& Zikri, A. (2020). Pengaruh Pendekatan Realistic Mathematics Education Terhadap Motivasi Dan Hasil Belajar Materi Matematika Di Sekolah Dasar. Jurnal Basicedu, 4(1), 203-209. Https://Doi.Org/10.31004/Basicedu.V4i1.325

Fadhilaturrahmi, F., Ananda, R., \& Yolanda, S. (2021). Persepsi Guru Sekolah Dasar Terhadap Pembelajaran Jarak Jauh Di Masa Pandemi Covid 19. Jurnal Basicedu, 5(3), 1683-1688. 
3676 Pengaruh Model Kooperatif Tipe Think Pair Share terhadap Motivasi dan Kemampuan Komunikasi Matematis Siswa Sekolah Dasar - Bella Putri Zain, Riska Ahmad

DOI: https://doi.org/10.31004/basicedu.v5i5.1408

Fatimah, N. (2015). Implementasi Cooperative Learning Tipe Think-Pair-Share Dalam Pembelajaran Bercerita Di Sekolah Menengah Pertama. Jurnal Penelitian Humaniora, 16(2), 90-98.

Fitri, R., S, N., \& Zikri, A. (2019). Pembelajaran Pkn Dengan Model Cooperative Learning Tipe Talking Stick. Jurnal Basicedu, 3(2), 524-532.

Husada, S. P., Taufina, T., \& Zikri, A. (2020). Pengembangan Bahan Ajar Pembelajaran Tematik Dengan Menggunakan Metode Visual Storytelling Di Sekolah Dasar. Jurnal Basicedu, 4(2), 419-425.

Irianto, P. O. (2016). Pengaruh Model Pembelajaran Kooperatif Tipe Think Pair Share Terhadap Keterampilan Menulis Teks Deskripsi Siswa Kelas Vii Smp Negeri 1 Padang. 2(November), 1-9.

Miaz, Y. (2012). Penggunaan Pendekatan Sains Teknologi Masyarakat Untuk Meningkatkan Hasil Belajar Siswa Dalam Pembelajaran Ips Kelas Iv Sdn 01 Baringin Anam Baso Kabupaten Agam. (350), 1-53.

Roqib, M. (2013). Pendidikan Karakter Dalam Perspektif Profetik. Jurnal Pendidikan Karakter, 3(3), 240249.

Sugiyono. (2013). Metode Penelitian Pendidikan Pendekatan Kuantitaif, Kualitatif, Dan R\&D. Bandung: Alfabeta.

Taufina, T., Chandra, C., Fauzan, A., \& Ilham Syarif, M. (2019). Development Of Statistics In Elementary School Based Rme Approach With Problem Solving For Revolution Industry 4.0. 382(Icet), 716-721. Https://Doi.Org/10.2991/Icet-19.2019.172

Vivi, L., Fitria, Y., Miaz, Y., \& Ahmad, Z. (2020). Pembelajaran Ipa Dengan Strategi Pembelajaran Inkuiri Untuk Meningkatkan Keterampilan Proses Sains Dan Motivasi Belajar Siswa Di Sekolah Dasar. Jurnal Basicedu.

Wyn, N., Sutrisni, P., Suadnyana, I. N., \& Suardika, I. W. R. (N.D.). Pengaruh Model Pembelajaran Kooperatif Tipe Think Pairs Share Berbasis Sains Teknologi Masyarakat Terhadap Hasil Belajar Ipa Siswa Kelas V Sd.

Yulia, -, Fauzan, A., Gistituati, N., \& Yerizon, -. (2018). Developing A Learning Trajectory For Teaching Set In Secondary Grade. 285(Icm2e), 236-241. Https://Doi.Org/10.2991/Icm2e-18.2018.54

Zaroha, L. (2019). The Effect Of Using Quantum Teaching And Motivation In Learning Toward Students Achievement. Jaiptekin, 3(1), 9-15. 